\title{
MANAJEMEN BIMBINGAN DAN KONSELING DI SMA MA'ARIF NGAWI
}

\author{
KHOLIFATUL KHASANAH \\ Institut Agama Islam Negeri (IAIN) Salatiga \\ Email: kholifahhasanah932@gmail.com
}

\begin{abstract}
Implementation of guidance and counselling in educational planning required management guidance and counselling that is well-systemized by the parties providing guidance and counselling in schools. Therefore it becomes interesting for researchers to research educational institutions in Ma'arif Ngawi High School. From the background picture behind the formulation of the problem that arises is how is the process of planning, organizing, implementing, to supervising or evaluating guidance and counselling that is applied at Ma'arif Ngawi High School. This research is qualitative. The informants of this study were the guidance and counselling teacher at Ma'arif Ngawi High School. The research data collection method was conducted by interview, observation, and documentation. Data analysis was performed with qualitative analysis which included data collection, data education, data presentation and conclusion collection. The results of this published research on Ma'arif High School apply guidance and counselling management in providing services to students. Proven in terms of planning, Maakah High School explained several processes that discuss the needs of students, the school needs analysis, setting goals, choosing the type of service, determining the time and place of activity, and determining facilities and budgets. The organizing phase also involves several processes of the division of guidance and counselling tasks, socialization of work methods, and coordination with stakeholders. The implementation phase of the process is following the planning that has been prepared following the program that has been designed. However, the implementation of the program based on research, namely the implementation of the wrong service program. Finally, the review also discusses the process of evaluating work results, evaluating work results and making decisions for improvement and development.
\end{abstract}

Keywords: Management, Guidance, Counseling 
Abstrak: Pelaksanaan bimbingan dan konseling dalam institusi pendidikan diperlukan manajemen bimbingan dan konseling yang tersistem dengan baik oleh pihak-pihak penyelenggara bimbingan dan konseling di sekolah. Oleh sebab itu menjadi sebuah hal yang menarik bagi peneliti untuk melakukan penelitian di lembaga pendidikan yaitu di SMA Ma'arif Ngawi. Dari gambaran latarbelakang tersebut rumusan masalah yang muncul adalah bagaimana proses perencanaan, pengorganisasian, pelaksanaan, hingga pengawasan atau evaluasi bimbingan dan konseling yang diterapkan di SMA Ma'arif Ngawi. Penelitian ini termasuk jenis penelitian kualitatif. Informan penelitian ini adalah guru bimbingan dan konseling SMA Ma'arif Ngawi. Metode pengumpulan data penelitian ini dilakukan dengan wawancara, observasi, dan dokumentasi. Analisa data dilakukan dengan analisis kualitatif yang meliputi pengumpulan data, redukasi data, penyajian data dan penarikan kesimpulan. Hasil penelitian ini diketahui bahwa SMA Ma'arif menerapkan manajemen bimbingan dan konseling dalam memberikan pelayanan kepada peserta didik. Dibuktikan dalam hal perencanaan, SMA Ma'arif meliputi beberapa proses diantaranya menganalisis kebutuhan siswa, analisis kondisi sekolah, penetapan tujuan, penentuan jenis layanan, penentuan waktu dan tempat kegiatan, serta penentuan fasilitas dan anggaran. Tahap pengorganisasian juga terdapat beberapa proses diantaranya pembagian petugas bimbingan dan konseling, sosialisasi cara kerja, serta koordinasi dengan stakeholder. Tahap pelaksanaan prosesnya sesuai dengan perencanaan yang telah disusun yaitu sesuai dengan program yang telah dirancang. Namun pada tahap pelaksanaan berdasarkan hasil penelitian terdapat kelemahan, yaitu tidak terlaksananya pelayanan salah satu program. Terakhir tahap evaluasi juga terdapat beberapa proses diantaranya adalah pencatatan hasil kerja, menilai hasil kerja dan mengambil tindakan perbaikan dan pengembangan.

Kata Kunci: Manajemen, Bimbingan dan Konseling. 


\section{A. Pendahuluan}

Depdiknas tahun 2008 menetapkan bahwa pendidikan yang bermutu, efektif dan ideal adalah yang mengintegrasikan tiga bidang kegiatan utamanya secara sinergi, yaitu bidang administratif dan kepemimpinan, bidang instruksional atau kurikuler serta bidang bimbingan dan konseling. ${ }^{1}$ Lebih lanjut dijelaskan bahwa, pendidikan yang hanya melaksanakan bidang administratif dan instruksional dengan mengabaikan bidang bimbingan dan konseling hanya akan menghasilkan konseli yang pintar dan trampil dalam aspek akademik, tetapi kurang memiliki kemampuan atau kematangan dala aspek kepribadian.

Kaitan bimbingan dan konseling dalam hal ini adalah membantu individu untuk menjadi insan yang berguna dalam hidupnya yang memiliki wawasan, pandangan, interpretasi, pilihan, penyesuaian dan ketrampilan yang tepat berkenaan dengan diri sendiri dan lingkungannya.

Agar pelayanan bimbingan dan konseling dapat berjalan secara optimal maka konselor sekolah memerlukan kegiatan manajerial yang baik, dan

${ }^{1}$ Depdiknas, Penataan Pendidikan profesional Konselor dan Layanan Bimbingan dan Konseling dalam Jalur pendidikan Formal (Jakarta: Depdiknas, 2008), hal. 194. kemampuan manajerial sesungguhnya merupakan salah satu kompetensi yang wajib dimiliki oleh konselor sekolah. Permendiknas No 27 Tahun 2008 tentang Standar Kualifikasi Akademik dan Kompetensi Konselor menyatakan bahwa seorang konselor sekolah harus menguasai semua kompetensi yang telah ditentukan, salah satu kompetensi yang wajib dikuasai adalah kompetensi profesional ke 13-15 yaitu seorang konselor dituntut mampu melakukan manajemen bimbingan dan konseling. Manajemen bimbingan dan konseling adalah segala aktivitas yang dimulai dari perencanaan, pengorganisasian, pelaksanaan dan evaluasi di bidang bimbingan dan konseling.

Mengingat pentingnya bimbingan dan konseling dalam institusi pendidikan maka untuk tercapainya tujuan layanan BK maka diperlukan sebuah konsep dan manajemen yang tersistem dengan baik oleh pihak-pihak penyelenggara BK di sekolah.

Dengan demikian seorang guru bimbingan dan konseling sebagai pelaksana dari layanan bimbingan dan konseling itu sendiri dituntut untuk memberikan layanan semaksimal mungkin sesuai dengan kebutuhan para 
siswa dan semua itu untuk mencapai kebahagiaan hidup di dunia dan akhirat.

Dalam penelitian ini penulis ingin meneliti tentang manajemen bimbingan dan konseling yang diterapkan di sekolah. Dalam hal ini, lembaga yang akan menjadi obyek penelitian adalah SMA Ma'arif Beran Ngawi sebagai lembaga pendidikan tingkat SMA yang berbasis Islam.

\section{B. Metode Penelitian}

Generasi milenial memiliki karakter unik berdasarkan wilayah dan kondisi sosial-ekonomi. Salah satu ciri utama generasi milenial ditandai oleh peningkatan penggunaan dan keakraban dengan komunikasi, media, dan teknologi digital. Karena dibesarkan oleh kemajuan teknologi, generasi milenial memiliki ciri-ciri kreatif, informatif, mempunyai passion dan produktif². Dibandingkan generasi sebelumnya, mereka lebih berteman baik dengan teknologi. Generasi ini merupakan generasi yang melibatkan teknologi dalam segala aspek kehidupan. Bukti nyata yang dapat diamati adalah hampir seluruh individu dalam generasi tersebut memilih menggunakan ponsel

${ }^{2}$ Ibid., hal. 18. pintar. Dengan menggunakan perangkat tersebut para milennials dapat menjadi individu yang lebih produktif dan efisien. Dari perangkat tersebut mereka mampu melakukan apapun dari sekadar berkirim pesan singkat, mengakses situs pendidikan, bertransaksi bisnis online, hingga memesan jasa transportasi online. Oleh karena itu, mereka mampu menciptakan berbagai peluang baru seiring dengan perkembangan teknologi yang kian mutakhir ${ }^{3}$. Generasi ini mempunyai karakteristik komunikasi yang terbuka, pengguna media sosial yang fanatik, kehidupannya sangat terpengaruh dengan perkembangan teknologi, serta lebih terbuka dengan pandangan politik dan ekonomi ${ }^{4}$. Sehingga, mereka terlihat sangat reaktif terhadap perubahan lingkungan yang terjadi di sekelilingnya.

\section{Pembahasan}

\section{A. Perencanaan}

Perencanaan merupakan kegiatan yang dilakukan pertama kali dalam melakukan suatu pengelolaan atau manajemen. Sebagaimana dipaparkan oleh kepala sekolah

${ }^{3}$ Ibid., hal. 19.

${ }^{4}$ Badan Pusat Statistik, Statistik Gender Tematik: Profil Generasi Millenial, (Jakarta: KemenPPA, 2018), hal. 14. 
bahwa yang diusulkan oleh kepala sekolah yang pertama adalah perencanaan program yang diantaranya adalah aggaran bimbingan dan konseling, sarana dan prasarana yang mendukung kegiatan bimbingan dan konseling. ${ }^{5}$

Berdasarkan hasil wawancara dengan konselor SMA Ma'arif Ngawi bahwa ada beberapa hal yang harus dipersiapkan dalam merencanakan sebuah program bimbingan dan konseling yaitu mengetahui kebutuhan siswa, analisis kondisi dan situasi sekolah, penentuan tujuan, penentuan jenis, teknik, dan strategi layanan, penentuan waktu, tempat, dan juga penentuan fasilitas dan anggaran. ${ }^{6}$ Di SMA Ma'arif Ngawi wujud dari hasil perencanaan adalah program bimbingan dan konseling. Proses perencanaan kegiatan yang dilakukan konselor adalah meliputi:

1. Analisis Kebutuhan Siswa

Pertama yang dilakukan konselor dalam perencanaan program bimbingan dan konseling adalah melakukan analisis kebutuhan dan

${ }^{5}$ Wawancara dengan Bapak Afifuddin Khoir selaku Kepala Sekolah SMA Ma'arif Ngawi pada tanggal 20 Januari 2015.

${ }^{6}$ Wawancara dengan Bapak Afifuddin khoir selaku Konselor SMA Ma'arif Ngawi pada tanggal 21 Januari 2015. permasalahan siswa, karena hasil analisis kebutuhan dan permasalahan siswa akan menentukan tujuan dari program bimbingan dan konseling dan merupakan dasar dalam membuat program bimbingan dan konseling. Analisis kebutuhan adalah kegiatan dimana konselor mengumpulkan semua data tentang siswa yang dibinanya baik data personel, data latar belakang siswa, data lingkungan sosial siswa dan data-data lain. Kegiatan analisis permasalahan dan kebutuhan siswa di SMA Ma'arif Ngawi dinyatakan oleh konselor sekolah yaitu Bapak Afifuddin Khoir bahwa ${ }^{7}$

"yang perlu diperhatikan dalam melakukan perencanaan adalah need assessment dengan cara menyebar angket DCM pada saat tahun ajaran baru, dari situlah terlihat kebutuhan siswa, apa saja pelayanan yang perlu diberikan kepada siswa dan hal tersebutlah yang menjadi dasar dalam penyusunan program BK".

Berdasarkan hasil observasi peneliti tidak menemukan konselor menyebarkan angket DCM, karena sesuai hasil wawancara bahwa

${ }^{7}$ Wawancara dengan Bapak Afifuddin Khoir selaku Konselor SMA Ma'arif Ngawi pada tanggal 21 januari 2015. 
penyebaran angket DCM dilaksanakan pada awal tahun ajaran baru, sementara peneliti mengadakan penelitian di tengah tahun ajaran, yaitu pada saat akhir semester pertama. $^{8}$

Berdasarkan hasil wawancara dan dokumentasi, dapat disimpulkan bahwa SMA Ma'arif Ngawi memiliki alat instrument BK dan data-data siswa yang digunakan untuk menganalisis kebutuhan dan permasalahan siswa yaitu DCM, hal ini berarti sesuai dengan pernyataan hasil wawancara dengan konselor.

Bapak Afifuddin mengungkapkan bahwa dalam kegiatan analisis kebutuhan siswa melibatkan kepala sekolah, wali kelas, guru mata pelajaran, dan TU. ${ }^{9}$ Hal senada juga diungkapkan oleh staf TU SMA Ma'arif bahwa ${ }^{10}$

"TU juga terlibat dalam perencanaan bimbingan dan konseling, dengan membantu menyiapkan sarana dan prasarana yang dibutuhkan dalam penyelenggaraan bimbingan dan konseling, selain itu juga membantu mempersiapkan data-data siswa yang

${ }^{8}$ Hasil observasi di SMA Ma'arif tanggal 19 Januari 2015.

${ }^{9}$ Wawancara dengan Bapak Afifuddin Khoir selaku Konselor SMA Ma'arif Ngawi pada tanggal 21 januari 2015.

${ }^{10}$ Wawancara dengan Ibu Vivit Khasanatur Rohmah selaku TU SMA Ma'arif Ngawi pada tanggal 24 januari 2015. sekiranya dibutuhkan dalam bimbingan dan konseling".

Berdasarkan hasil observasi peneliti juga menemukan bahwa dalam melakukan pelayanan proses konseling, konselor bekerja sama dengan TU untuk mendapatkan data mengenai anak yang mengalami masalah. ${ }^{11}$

Berdasarkan hal-hal tersebut diatas maka peneliti dapat menyimpulkan bahwa konselor SMA Ma'arif Ngawi melakukan kegiatan analisis kebutuhan dan permasalahan siswa dibuktikan dengan adanya alat istrumentasi BK dan data-data siswa diruang BK, serta adanya kegiatan instrumentasi BK pada program BK, sehingga program yang akan dibuat dapat tepat sasaran sesuai dengan kebutuhan peserta didik, dan peserta didik dapat mencapai perkembangan yang optimal.

2. Analisis Kondisi dan Situasi Sekolah

Kegiatan

perencanaan selanjutnya adalah analisis situasi dan kondisi sekolah yang meliputi kegiatan mencari data tentang keadaan sekolah mulai dari kebijakan

\footnotetext{
2015
} 
sekolah sampai dengan segala faktor yang ada di sekolah yang bisa mempengaruhi siswa dalam pelaksanaan bimbingan dan konseling. Adapun jadwal kehadiran guru bimbingan dan konseling di SMA Ma'arif Ngawi, sebagai berikut: ${ }^{12}$

\begin{tabular}{|l|c|c|c|c|c|c|c|}
\hline \multirow{2}{*}{ Nama Guru BK } & \multirow{2}{*}{ Kelas } & \multicolumn{5}{|c|}{ Kehadiran } \\
\cline { 3 - 8 } & & Senin & Selasa & Rabu & Kamis & Jumat & Sabtu \\
\hline $\begin{array}{l}\text { AHMAD } \\
\text { HAWARIYIN }\end{array}$ & $\mathbf{X}$ & & & & & & \\
\hline $\begin{array}{l}\text { YATNO } \\
\text { SUGIANTO }\end{array}$ & XI & & & & & & \\
\hline $\begin{array}{l}\text { HAMDAN } \\
\text { ABIWAQOS }\end{array}$ & XII & & & & & & \\
\hline
\end{tabular}

\section{Penentuan Tujuan}

Berdasarkan hasil wawancara dengan kepala sekolah bahwa Penentuan tujuan merupakan kegiatan konselor setelah didapatkan data tentang kebutuhan siswa dan kondisi yang ada pada sekolah. Tujuan dari bimbingan dan konseling merupakan cerminan dari visi misi sekolah, sehingga dalam menetapkan tujuan program bimbingan dan konseling harus disesuaikan dengan visi dan misi sekolah tetapi pelaksanaannya mengikuti kondisi yang terjadi. ${ }^{13}$

\footnotetext{
${ }^{12}$ Hasil dokumentasi bimbingan dan konseling SMA Ma'arif Ngawi pada tanggal 30 Januari 2015.

${ }^{13}$ Wawancara dengan Bapak Afifuddin Khoir selaku Kepala Sekolah SMA Ma'arif Ngawi pada tanggal 21 januari 2015.
}

Pelibatan stakeholder dalam penentuan tujuan program bimbingan dan konseling dapat diwujudkan dengan memberikan usulan atau masukan, tetapi tidak semua personel sekolah memberikan masukan atau usulan perencanaan, pemberi usulan penyusunan program BK adalah kepala sekolah, wakil kepala sekolah dan wali kelas. Pemberian usulan dilakukan pada saat program BK berjalan.

Berdasarkan pernyataan diatas maka dapat disimpulkan bahwa tujuan bimbingan dan konseling di SMA Ma'arif Ngawi bersifat kontemporer artinya bisa berubah sesuai dengan kondisi yang terjadi pada saat itu dan pemberian usulan dalam penyusunan program dilakukan oleh kepala sekolah dan wakil kepala sekolah sedangkan personel yang lain memberikan masukan saat program BK telah berjalan.

4. Penentuan Jenis Layanan

Penentuan jenis layanan mengacu pada tujuan bimbingan dan konseling, Bapak Afifuddin menyatakan adanya keprioritasan dalam jenis layanan yang diberikan 
yaitu ditujukan untuk kelas X dan XII, penetapan jenis layanan disebutkan di program BK SMA Ma'arif. ${ }^{14}$

Jenis layanan di SMA Ma'arif Ngawi adalah: ${ }^{15}$

a. Orientasi, yaitu layanan yang membantu peserta didik memahami lingkungan baru, terutama lingkungan sekolah/madrasah dan obyekobyek yang dipelajari, untuk menyesuaikan diri serta mempermudah dan memperlancar peran peserta didik di lingkungan yang baru.

b. Informasi, yaitu layanan yang membantu peserta didik menerima, memahami berbagai informasi diri, sosial, belajar, karir/jabatan, dan pendidikan lanjutan.

c. Penempatan dan Penyaluran, yaitu layanan yang membantu peserta didik memperoleh penempatan dan penyaluran yang tepat di dalam kelas, kelompok belajar, jurusan/program studi, program

\footnotetext{
${ }^{14}$ Wawancara dengan Bapak Afifuddin Khoir selaku Konselor SMA Ma'arif Ngawi pada tanggal 21 januari 2015.

${ }^{15}$ Dokumentasi dari program bimbingan dan konseling SMA Ma'arif Ngawi pada tanggal 30 Januari 2015.
}

latihan, magang, dan kegiatan ekstra kurikuler.

d. Pembelajaran, yaitu layanan yang membantu peserta didik menguasai konten tertentu, terumata kompetensi atau kebiasaan yang berguna dalam kehidupan di sekolah, keluarga, dan masyarakat.

e. Konseling individual, yaitu layanan yang membantu peserta didik dalam mengentaskan masalah pribadinya.

f. Bimbingan individual yaitu layanan yang membantu peserta didik dalam pengembangan pribadi, kemampuan hubungan sosial, kegiatan belajar, karir/jabatan, dan pengambilan keputusan.

g. Konseling Kelompok, yaitu layanan yang membantu peserta didik dalam pembahasan pengentasan masalah pribadi melalui dinamika kelompok.

h. Bimbingan kelompok, bantuan kepada individu yang dilakukan melalui dinamika kelompok.

5. Penentuan Waktu dan Tempat kegiatan

Berdasarkan hasil wawancara dengan konselor sekolah bahwa 
penentuan waktu dan tempat kegiatan akan dibahas dalam rapat pembentukan program $\mathrm{BK}^{16}$ hal senada juga disampaikan oleh staf TU bahwa dalam penentuan waktu dan tempat pelaksanaan kegiatan bimbingan dan konseling berdasarkan rapat bersama seluruh anggota sekolah mulai kepala sekolah, wakil, konselor sekolah, wali kelas, guru mata pelajaran dan TU. ${ }^{17}$

Sehingga dapat diketahui bahwa Di SMA Ma'arif tidak terdapat waktu khusus jam pelajaran di dalam kelas, oleh karena itu pelaksanaan pelayanan bimbingan dan konseling dilaksanakan hanya di luar kelas, diantaranya saat setelah sholat dhuha berjamaah, saat jam kosong, saat suasana genting serta saat hari-hari tertentu tergantung situasi dan kondisi.

6. Penetapan Fasilitas dan Anggaran Menurut beliau Bapak Afifuddin Khoir sebagai kepala sekolah mengungkapkan bahwa kebutuhan untuk melengkapai fasilitas dan perlengkapan bimbingan dan

\footnotetext{
${ }^{16}$ Wawancara dengan Bapak Afifuddin Khoir selaku Konselor SMA Ma'arif Ngawi pada tanggal 21 januari 2015.

${ }^{17}$ Wawancara dengan Ibu vivit selaku TU SMA Ma'arif Ngawi pada tanggal 24 januari 2015.
}

konseling SMA Ma'arif Ngawi sudah dimasukkan dalam RKAS tahunan. ${ }^{18}$ Berdasarkan hasil wawancara dengan konselor bahwa, ${ }^{19}$

"Anggaran biaya disesuaikan dengan RKAS (Rencana Kegiatan Anggaran Sekolah), dengan cara konselor membuat proposal kegiatan bimbingan dan konseling, mengenai perlengkapan yang diperlukan, sementara itu pembiayaan yang terkait dengan psikotes dibebankan kepada orang tua siswa dengan persetujuan komite sekolah"

Pelaksanaannya koordinator BK mengajukan proposal mengenai perlengkapan yang diperlukan, kepala sekolah menyetujui berdasarkan anggaran yang tersedia. Meskipun saat ini keperluan sarana bimbingan dan konseling masih terbatas namun koordinator dan staf BK bekerja seoptimal mungkin memberikan layanan bimbingan kepada siswa. Pembiayaan yang berkaitan dengan kegiatan psikotest dibebankan kepada orang tua siswa

\footnotetext{
${ }^{18}$ Wawancara dengan Bapak Afifuddin Khoir selaku Kepala Sekolah SMA Ma'arif Ngawi pada tanggal 20 januari 2015.

${ }^{19}$ Wawancara dengan Bapak Afifuddin Khoir selaku Konselor SMA Ma'arif Ngawi pada tanggal 21 januari 2015.
} 
dengan persetujuan pihak komite sekolah.

Setelah mengetahui proses perencanaan program di SMA Ma'arif Ngawi yang meliputi analisis kebutuhan siswa, analisis situasi dan kondisi sekolah, penentuan tujuan, penentuan jenis, teknik dan strategi kegiatan, penentuan waktu dan tempat kegiatan serta penentuan fasilitas dan anggaran biaya. Menunjukkan bahwa dalam proses penyusunan program bimbingan dan konseling SMA Ma'arif Ngawi melewati beberapa tahapan sehingga dapat menghasilkan program yang benar-benar dibutuhkan atau sesuai dengan kebutuhan peserta didik.

\section{B. Pengorganisasian}

Diungkapkan juga oleh kepala sekolah Bapak Afifuddin Khoir bahwa Pengorganisasian merupakan faktor penting karena dalam pengorganisasian diperlukan penempatan personel yang tepat pada setiap tugas yang ada di organisasi bimbingan dan konseling dan perlu koordinasi yang baik agar tujuan organisasi dapat dicapai. ${ }^{20}$

Berikut

ini

proses pengorganisasian manajeman bimbingan dan konseling yang terdapat di SMA Ma'arif Ngawi, meliputi:

1. Pembagian Petugas Bimbingan dan Konseling

SMA Ma'arif pembagian tugas konselor berfungsi agar terdapat kejelasan atas tugas masing-masing konselor dalam organisasi bimbingan dan konseling, kegiatan pembagian tugas ini merupakan kegiatan pengorganisasian yang dilakukan untuk mempermudah konselor melakukan perencanaan program, hal ini di ungkapkan oleh Bapak Afifuddin Khoir, menurut beliau setelah pembagian tugas dalam bimbingan dan konseling dibentuk, maka semua personel dapat mengetahui tugasnya masingmasing. ${ }^{21}$ Berikut ini merupakan struktur organisasi bimbingan dan konseling di SMA Ma'arif Ngawi.

\footnotetext{
${ }^{20}$ Wawancara dengan Bapak Afifuddin Khoir selaku Kepala Sekolah SMA Ma'arif Ngawi pada tanggal 20 januari 2015.

${ }^{21}$ Wawancara dengan Bapak Afifuddin Khoir selaku konselor SMA Ma'arif Ngawi pada tanggal 20 januari 2015.
} 
Tabel 1 Struktur Organisasi BK SMA Ma'arif Ngawi.

\begin{tabular}{|c|c|c|}
\hline No & Jabatan & Nama \\
\hline 1 & Penanggung Jawab & Afifuddin Khoir, S.Psi., M.Pd.I. \\
\hline 2 & Koordinator BK & Afifuddin Khoir, S.Psi.. M.Pd.I. \\
\hline 3 & Sekretaris & Estherina Sudianti, S.Pd.Si \\
\hline 4 & Bendahara & Desi Prihatiningsih \\
\hline 5 & Data & Ikhsanudin \\
\hline 6 & Sarana dan Prasarana & Thoha Ma'shum \\
\hline
\end{tabular}

dapat disimpulkan bahwa kegiatan pembagian tugas bimbingan konseling dilakukan guna memudahkan pembagian sasaran bimbingan dan konseling dan pembagian tugas bimbingan dan konseling yang dilakukan disesuaikan dengan kemampuan yang dimiliki oleh konselor. Wujud dari pembagian tugas adalah struktur organisasi BK.

2. Sosialisasi cara kerja Bimbingan dan konseling

Diungkapkan oleh konselor sekolah berdasarkan hasil wawancara bahwa sosialisasi cara kerja yang dilakukan oleh petugas bimbingan dan konseling bertujuan agar stakeholder mengetahui kerja konselor sehingga stakeholder dapat mengetahui pelaksanaan kegiatan bimbingan dan konseling. ${ }^{22}$

${ }^{22}$ Wawancara dengan Bapak Afifuddin Khoir selaku Konselor SMA Ma'arif Ngawi pada tanggal 21 januari 2015.
Sementara itu, kepala sekolah mengungkapkan bahwa konselor memberikan orientasi bimbingan dan konseling pada awal tahun ajaran baru sedangkan sosialisasi kepada orang tua dilakukan pada saat rapat, sementara orientasi kepada siswa juga tertulis di dalam program $\mathrm{BK}^{23}$ Dan sosialisai kepada guru dan karyawan juga dilakukan oleh konselor. Dibuktikan dengan hasil wawancara dengan salah satu staf TU, mengungkapkan bahwa dalam sosialisasinya konselor memberikan pengertian cara kerjanya yaitu membantu peserta didik dalam memahami bakat dan minat serta memabantu peserta didik dalam mengembangkan kemampuan belajar. ${ }^{24}$

3. Pelibatan dan Koordinasi dengan Stakeholder

Di SMA Ma'arif Ngawi Pelibatan dan koordinasi dengan stakeholder merupakan kegiatan dimana konselor melibatkan pihak-pihak yang akan terkait dengan pelaksanaan kegiatan bimbingan dan konseling dan

${ }^{23}$ Wawancara dengan Bapak Afifuddin Khoir selaku Kepala Sekolah SMA Ma'arif Ngawi pada tanggal 20 januari 2015.

${ }^{24}$ Wawancara dengan Ibu Vivit selaku TU SMA Ma'arif Ngawi pada tanggal 24 januari 2015. 
melakukan koordinasi dengan stakeholder termasuk wakil kepala sekolah, wali kelas, guru mata pelajaran, dan karyawan TU. ${ }^{25}$

Pelibatan dan koordinasi diungkapkan oleh kepala sekolah bahwa proses koordinasi harus dilakukan sebab dalam pengambilan kebijakan tidak dapat dilakukan secara sendiri melainkan harus ada koordinasi dengan segenap stakeholder. ${ }^{26}$

Sementara staf TU Ibu Vivit Khasanatur Rohmah, juga mengungkapkan hal yang sama yaitu dalam koordinasi dilakukan secara musyawarah bersama untuk mencari jalan keluar yang terbaik dalam setiap permasalahan, membantu memberikan data pribadi siswa jika diperlukan. ${ }^{27}$

Sehingga dengan koordinasi dan kerjasama yang harmonis antara konselor, guru mata pelajaran, wali kelas serta TU maka konselor dengan mudah memantau kondisi siswa dalam seluruh kegiatan pembelajaran

\footnotetext{
${ }^{25}$ Wawancara dengan Bapak Afifuddin Khoir selaku Konselor SMA Ma'arif Ngawi pada tanggal 21 januari 2015.

${ }^{26}$ Wawancara dengan Bapak Afifuddin Khoir selaku Kepala Sekolah SMA Ma'arif Ngawi pada tanggal 20 januari 2015.

${ }^{27}$ Wawancara dengan Iibu Vivit selaku TU SMA Ma'arif Ngawi pada tanggal 24 januari 2015
}

yang dilaksanakan di sekolah. Sebab konselor dalam hal ini tidak mungkin dapat memantau langsung kegiatan yang dilakukan oleh siswa, pemantauan dapat dilimpahkan kepada guru mata pelajaran dan guru wali kelas untuk kemudian konselor menerima informasi dari guru mata pelajaran dan wali kelas tersebut.

\section{Berdasarkan}

pernyataanpernyataan diatas dapat disimpulkan bahwa pelibatan kepala sekolah terkait dengan kebijakan dan penanganan masalah, wakil kepala sekolah dengan penanganan masalah, wali kelas terkait dengan informasi tentang siswa dan penanganan masalah siswa, guru mata pelajaran terkait analisis nilai, dan TU terkait dengan data dan form-form surat, sehingga dapat disimpulkan di SMA Ma'arif adanya pelibatan dan koordinasi dan terjalin kerja sama yang baik antara konselor dan personel sekolah yang lain.

Setelah mengetahui proses pengorganisasian di SMA Ma'arif dapat diketahui bahwa prosesnya adalah dimulai dari pembagian petugas bimbingan dan konseling yang disesuaikan dengan kemampuan 
yang dimiliki, kemudian sosialisasi cara kerja bimbingan dan konseling dan yang terakhir adalah pelibatan dan koordinasi dengan stakeholder dan saling menjaga keharmonisan dan berkomitmen demi pelaksanaan perencanaan program yang telah dibuat.

\section{Pelaksanaan}

Fungsi manajemen bimbingan dan konseling selanjutnya yang tidak dapat dipisahkan adalah pelaksanaan, setelah tahap sebelumnya perencanaan, pengorganisasian tahap selanjutnya ini adalah pelaksanaan. Di SMA Ma'arif Pelaksanaan kegiatan bimbingan dan konseling merupakan inti dari manajemen bimbingan dan konseling, hal ini dikarenakan dalam pelaksanaan konselor akan menunjukkan action terhadap sasaran mereka sesuai dengan program yang telah direncanakan. Wujud dari pelaksanaan bimbingan dan konseling adalah pelaksanaan layanan BK dan kegiatan pendukung BK.

Pelaksanaan layanan bimbingan dan konseling mengacu pada tujuan bimbingan dan konseling, di SMA Ma'arif berdasarkan hasil wawancara dengan konselor sekolah Bapak Afifuddin Khoir bahwa layanan bimbingan dan konseling mengarah kepada empat bidang layanan yaitu bidang pribadi, sosial, belajar dan karir, dan keempat bidang tersebut diberikan kepada semua tingkatan kelas. $^{28}$

Di SMA Ma'arif ini pemberian layanan kepada siswa dilakukan secara kelompok dan individual, sedangkan untuk layanan klasikal dilakukan tergantung situasi dan kondisi yang memungkinkan untuk dilakukan bimbingan, seperti pada saat jam kosong, atau pada saat terjadi hal-hal penting yang mendesak meminta jam guru atau wali kelas.

Pada saat penelitian, peneliti tidak melihat konselor melakukan kegiatan bimbingan kelompok dan konseling kelompok akan tetapi Bapak afifuddin mengungkapkan bahwa kegiatan bimbingan dan konseling disisipkan pada saat setelah sholat dhuha berjamaah, dan pada

${ }^{28}$ Wawancara dengan Bapak Afifuddin Khoir selaku Konselor SMA Ma'arif Ngawi pada tanggal 20 januari 2015 
hari minggu pada saat pengembangan diri berupa kegiatan ektrakurikuler. ${ }^{29}$

Adapun kegiatan layanan di SMA Ma'arif Ngawi ada 8 layanan yaitu sebagai berikut: ${ }^{30}$

1. Layanan Orientasi

Layanan orientasi ini merupakan kegiatan yang memungkinkan peserta didik untuk memahami dan menyesuaikan diri dengan lingkungan di SMA. Di SMA Ma'arif layanan orientasi dilaksanakan pada awal tahun pelajaran baru.

2. Layanan Informasi

Layanan informasi ini tentang berbagai hal yang dibutuhkan oleh siswa, bermanfaat untuk membantu belajar. Layanan ini diberikan melalui komunikasi langsung maupun tidak langsung.

3. Layanan Penempatan

Layanan penempatan pada dasarnya adalah layanan dari bimbingan dan konseling yang memungkinkan peserta didik memperoleh penempatan yang sesuai dengan dirinya.

4. Layanan Pembelajaran

\footnotetext{
${ }^{29}$ Wawancara dengan Bapak Afifuddin Khoir selaku Konselor SMA Ma'arif Ngawi pada tanggal 20 januari 2015

${ }^{30}$ Hasil Dokumentasi dari program bimbingan dan konseling SMA Ma'arif Ngawi pada tanggal 30 Januari 2015.
}

Layanan pembelajarannya meliputi, pengenalan kemampuan, motivasi, sikap, kebiasaan belajar, dan pengembangan ketrampilan belajar.

5. Layanan Konseling Individual

Layanan konseling individual yang diselenggarakan di SMA Ma'arif Ngawi ini bertujuan untuk membantu siswa memecahkan masalah yang sedang dihadapi di kehidupannya, bukan berarti konselor memberikan solusi melainkan siswa itu sendiri yang memutuskan jalan keluarnya.

6. Layanan Konseling Kelompok

Layanan bimbingan kelompok mencakup penggunaan waktu luang, bimbingan tingkah laku, dan bimbingan pelaksanaan disiplin.

Berdasarkan hasil wawancara dan hasil dokumentasi menunjukkan bahwa, semua bidang dan jenis layanan kegiatan bimbingan dan konseling di SMA Ma'arif didukung dengan kegiatan-kegiatan pendukung, meliputi:

1. Instrumen BK, yang meliputi angket siswa, angket penjurusan, dan tes psikologi.

2. Himpunan data, yang meliputi data pribadi, data presensi, data prestasi dan data tes psikologi. 
3. Konferensi kasus.

4. Kunjungan rumah.

5. Alih tangan kasus.

Sedangkan dalam mengatasi permasalahan siswa Bapak Afifuddin mengungkapkan bahwa ada tiga model yang selama ini diterapkan di SMA Ma'arif Ngawi dalam penanganan penyelesaian masalah: ${ }^{31}$

1. Berdasarkan rekomendasi dari wali kelas

2. Kesadaran siswa

3. Melalui alur seperti dalam bagan berikut ini.

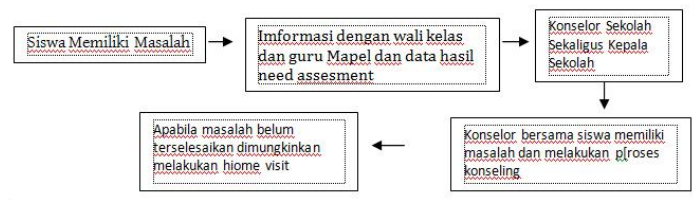

Berdasarkan hasil wawancara dengan konselor bahwa kegiatan pendukung yang diprioritaskan dalam pemberian layanan bimbingan dan konseling adalah kunjungan rumah. Karena mayoritas permasalahan siswa berkaitan dengan orang tua dan lebih baik jika orang tua juga mengetahui jika terjadi sesuatu kepada anak.

Pada waktu penelitian di SMA Ma'arif Ngawi, peneliti melihat pelaksanaan ini merupakan hal yang

${ }^{31}$ Wawancara dengan Bapak Afifuddin Khoir selaku Konselor SMA Ma'arif Ngawi pada tanggal 20 januari 2015 paling sulit setelah perencanaan dan pengorganisasian. Karena pelaksanaan ini merupakan action dari tahap perencanaan dan pengorganisasian.

\section{Evaluasi}

Evaluasi bimbingan dan konseling di SMA Ma'arif adalah kegiatan pemantauan atau pengontrolan atas kegiatan bimbingan dan konseling yang dilakukan oleh konselor agar kegiatan bimbingan dan konseling tetap mengarah pada pencapaian tujuan bimbingan dan konseling.

Proses kegiatan evaluasi manajemen bimbingan dan konseling SMA Ma'arif meliputi:

1. Pencatatan hasil kerja dan kinerja

Pencatatan hasil kerja dan kinerja adalah kegiatan yang dilakukan oleh konselor terkait dengan penulisan atas kegiatan yang telah dilakukan atau penulisan laporan bimbingan dan konseling. Berdasarkan hasil wawancara dengan konselor SMA Ma'arif Ngawi Bapak Afifuddin mengungkapkan bahwa bentuk laporan kegiatan bimbingan dan konseling di SMA Ma'arif Ngawi adalah laporan harian yakni setelah pemberian layanan dilakukan kemudian hasilnya dituliskan pada 
agenda harian. ${ }^{32}$ Dari catatan atau agenda harian tersebut dijadikan sebagai pedoman dalam penyusunan laporan bimbingan dan konseling. Beliau menambahkan bahwa dalam penulisan laporan tersebut dilakukan oleh konselor sendiri, namun untuk laporan secara keseluruhan dibantu oleh TU.

2. Mengukur dan menilai hasil kerja dan kinerja

Di SMA Ma'arif Ngawi Penilaian hasil kerja dan kinerja konselor dilakukan oleh pihak sekolah. Petugas yang melakukan penilaian dari dalam disebut auditor yang bertugas untuk menilai semua pelaksanaan manajemen di sekolah. Anggota auditor terdiri dari kepala sekolah, wakil kepala sekolah dan beberapa guru yang ditunjuk. Penilaian yang dilakukan di SMA Ma'arif meliputi program BK, laporan program BK, dan laporan siswa yang diterima diperguruan tinggi.

Selain itu berdasarkan hasil wawancara dengan konselor, untuk menilai hasil kerja dan kinerja konselor melakukan wawancara dan observasi, yaitu mewawancarai anak didik

${ }^{32}$ Wawancara dengan Bapak Afifuddin Khoir selaku Konselor SMA Ma'arif Ngawi pada tanggal 20 januari 2015. sendiri, dengan orang tua, temanteman dekat dan beberapa guru lainnya. Sementara observasi yang dilakukan konselor dilakukan pada saat istirahat, pada saat istirahat tersebut anak didik diperhatikan bagaimana ia bergaul dengan teman-temannya, bagaimana teman-temannya memperlakukan sang anak didik yang sedang di observasi. Tujuan konselor melakukan observasi ini adalah untuk mengetahui sejauh mana anak didik mengalami perubahan dalam pergaulan setelah beberapa kali melakukan pertemuan dalam bimbingan dan konseling.

3. Mengambil tindakan perbaikan dan pengembangan

Di SMA Ma'arif Ngawi setelah dilakukan penilaian atas kinerja konselor, langkah selanjutnya dalam evaluasi adalah melakukan tindakan perbaikan dan pengembangan apabila dari hasil pengawasan ditemukan hal yang dirasa menjadi kurang searah atau bahkan menjadi kendala dalam pencapaian tujuan. Di SMA Ma'arif tindak lanjut kegiatan BK ditujukkan pada apabila hasil evaluasi dari layanan Bimbingan dan Konseling tidak memberikan peningkatan, maka sesuai dengan analisis akan diadakan 
perbaikan program dan perbaikan proses untuk program di masa mendatang, yaitu program yang kurang berhasil dapat diperbaiki atau menggantinya dengan program baru yang dibutuhkan peserta didik sesuai dengan perkembangan siswa dan mengenai pelaksanaannya akan sangat memperhatikan waktu, suasana, tempat, dan lingkungan.

\section{Pembahasan}

Mengingat manajemen bimbingan dan konseling adalah suatu sistem yang saling terkait antara sub-subnya berikut ini merupakan penjabaran pembahasan berdasarkan hasil penelitian yang peneliti lakukan di SMA Ma'arif Ngawi.

\section{Perencanaan}

Setelah mengetahui proses perencanaan program di SMA Ma'arif Ngawi yang meliputi analisis kebutuhan siswa, analisis situasi dan kondisi sekolah, penentuan tujuan, penentuan jenis, teknik dan strategi kegiatan, penentuan waktu dan tempat kegiatan serta penentuan fasilitas dan anggaran biaya. Menunjukkan bahwa dalam proses penyusunan program bimbingan dan konseling SMA Ma'arif Ngawi melewati beberapa tahapan sehingga dapat menghasilkan program yang benar-benar dibutuhkan atau sesuai dengan kebutuhan peserta didik, sehingga menjadi jelas jenis kegiatannya, tujuan kegiatannya, waktu kegiatan, sasaran kegiatan, dan pelaksana kegiatannya. Sehingga tidak akan terjadi kerancuan dalam melaksanakan layanan bimbingan dan konseling,

Berdasarkan hasil penelitian tersebut di lihat dari sisi manajemen menunjukkan bahwa dalam proses perencanaan ini SMA Ma'arif sesuai dengan teori, bahwa dalam manajemen bimbingan dan konseling tahapan utamanya adalah perencanaan dan perencanaan bimbingan dan konseling perlu memperhatikan beberapa kegiatan yang harus dilalui meliputi analisis kebutuhan atau need assessment yaitu SMA Ma'arif memanfaatkan instrument angket berupa DCM (Daftar Cek Masalah) guna analisis kebutuhan siswa, selanjutnya analisis situasi dan kondisi sekolah, penentuan tujuan, penentuan jenis kegiatan, penentuan waktu dan tempat kegiatan, dan penentuan fasilitas anggaran biaya.

Di dalam SMA Ma'arif tersebut proses perencanaan berjalan sesuai dengan teori yang telah dikemukakan, 
maka setelah perencanaan dibuat dibentuklah petugas-petugas yang akan menjalankan perencanaan yang telah disusun yaitu dibentuklah suatu pengorganisasian.

2. Pengorganisasian

Dari hasil penelitian di SMA Ma'arif dapat diketahui bahwa proses pengorganisasian dimulai dari pembagian petugas bimbingan dan konseling yang disesuaikan dengan kemampuan yang dimiliki, kemudian sosialisasi cara kerja bimbingan dan konseling dan yang terakhir adalah pelibatan dan koordinasi dengan stakeholder.

Berdasarkan analisa peneliti dari sisi manajemen bahwa proses pengorganisasian yang dilaksanakan di SMA Ma'arif hal ini sesuai dengan teori. Pertama pembagian petugas personel bimbingan dan konseling memang diperlukan agar setiap personel mengetahui tugas masing-masing. Kedua, sosialisasi cara kerja bimbingan dan konseling, menurut analisa peneliti bahwa sosialisasi cara kerja bimbingan dan konseling memang harus dilaksanakan, agar stakeholder mengetahui secara keseluruhan cara kerja petugas bimbingan dan konseling dalam pengertian dalam pelaksanaan tidak terjadi tumpang antara petugas bimbingan dan konseling dan guru mata pelajaran atau sebaliknya, sehingga dengan adanya sosialisasi cara kerja bimbingan dan konseling, antara konselor dengan guru mata pelajaran, maupun dengan segenap personil sekolah mampu berjalan beriringan.

3. Pelaksanaan

Setelah penyusunan perencanaan dan pengorganisasian, sub sistem selanjutnya adalah pelaksanaan, yaitu pelaksanaan dari perencanaan yang telah disusun. Perencanaan yang telah disusun adalah berbagai macam layanan dan kegiatan pendukung. Layanan bimbingan dan konseling yang telah direncanakan di SMA Ma'arif adalah:

a. Layanan Orientasi

Layanan orientasi SMA Ma'arif mencakup pengenalan program sekolah dan program studi.

b. Layanan Informasi

Layanan informasi SMA Ma'arif mencakup cara belajar efektif, perkembangan dan pertumbuhan remaja, pergaulan dan tata karma, 
penjurusan, studi lanjutan perguruan tinggi, karir dan pekerjaan.

c. Layanan penempatan dan Penyaluran

Layanan penempatan yang mencakup pembagian kelas, pembagian pokjar, dan kelompok pilihan program studi.

d. Layanan Pembelajaran

Layanan pembelajaran yang mencakup pengenalan kemampuan, motivasi, sikap, kebiasaan belajar dan pengembangan ketrampilan belajar.

e. Layanan Konseling Individual

f. Layanan Bimbingan Individual

g. Layanan Konseling Kelompok

h. Layanan Bimbingan kelompok

Layanan bimbingan kelompok mencakup penggunaan waktu luang, bimbingan bertingkah laku, dan bimbingan pelaksanaan disiplin.

Sementara itu kegiatan pendukung yang telah direncanakan di SMA Ma'arif adalah penyediaan instrument berupa angket siswa dan angket penjurusan, himpunan data, data prestasi, data presesensi, dan data tes psikologi. Kegiatan pendukung lainnya adalah analisa data, konferensi kasus, referal, dan kunjungan rumah.
Berdasarkan analisa peneliti dari sudut pandang manajemen bahwa peneliti melihat di SMA Ma'arif pelaksanaan bimbingan dan konseling yang telah direncanakan sesuai dengan yang direncanakan dalam program yaitu melaksanakan pelayanan bimbingan dan konseling kepada peserta didik.

\section{Evaluasi}

Berdasarkan hasil penelitian dapat dipahami bahwa evaluasi bimbingan dan konseling yang dilakukan SMA Ma'arif Ngawi sesuai dengan teori, Bahwa kegiatan dalam evaluasi mencakup pencatatan hasil kerja dan kinerja, mengukur dan menilai hasil kerja, dan mengambil tindakan perbaikan dan pengembangan. Jadi setelah perencanaan yang disusun menjadi sebuah program bimbingan dan konseling, setelah berjalan selama satu tahun pelajaran program-program tersebut nantinya akan dievaluasi oleh auditor yang bertugas untuk melakukan penilaian. Penilaiannnya dilakukan dengan melihat laporan program bimbingan dan konseling yang telah disusun berdasarkan catatan-catatan harian petugas bimbingan dan konseling. Sehingga 
dengan evaluasi tersebut dapat diketahui kendala dalam pencapaian tujuan, dan untuk perbaikan program untuk program yang akan datang, tidak hanya dari sisi perencanaan akan tetapi juga perbaikan dalam pengorganisasian dan pelaksanaan.

\section{E. Penutup}

Manajemen Bimbingan dan Konseling yang diterapkan di SMA Ma'arif merupakan suatu proses yang saling berkaitan antara sub sistem-sub sistemnya, yaitu perencanaan, pengorganisasian, pelaksanaan dan evaluasi. Dengan adanya saling keterkaitan tersebut manajemen bimbingan dan konseling yang diterapkan diharapkan dapat mencapai tujuan, yaitu dapat memenuhi segala kebutuhan yang dibutuhkan oleh peserta didik dalam mencapai perkembangan optimal, dan dapat mencapai bakat dan minat dengan segala potensi yang dimiliki

Berdasarkan hasil penelitian tentang manajemen bimbingan dan konseling yang diterapkan di SMA Ma'arif maka dapat disimpulkan bahwa:

1. Proses perencanaan, di SMA Ma'arif berjalan dengan lancar dalam arti perencanaan dalam penyusunan program sesuai dengan teori yang peneliti gunakan, yaitu melalui tahapan analisis kebutuhan siswa, analisis kondisi sekolah, penetapan tujuan, penentuan jenis, teknik, strategi layanan, penentuan waktu dan tempat kegiatan, dan penentuan fasilitas dan anggaran.

2. Proses pengorganisasian di SMA Ma'arif Ngawi sesuai dengan teori yang peneliti gunakan, prosesnya meliputi pembagian petugas bimbingan dan konseling, sosialisasi cara kerja bimbingan dan konseling, serta pelibatan dan koordinasi dengan stakeholder.

3. Proses pelaksanaan SMA Ma'arif juga berjalan sesuai dengan teori yang peneliti gunakan, yakni bermacam-macam pelayanan bimbingan dan konseling diberikan kepada peserta didik walaupun dengan waktu yang terbatas.

4. Terakhir adalah evaluasi, tanpa evaluasi tidak dapat diketahui kekurangan atau kesalahan dalam perencanaan, pengorganisasian dan 


pelaksanaan yang telah
dilaksanakan. Di SMA Ma'arif
ngawi dalam evaluasi terdapat
beberapa proses yaitu pencatatan
hasil kerja, menilai hasil kerja,
yaitu dengan wawancara dan
observasi yang dilakukan kepada
peserta didik, guna mengetahui
apakah peserta didik mengalami
perubahan positif atau
sebaliknya, kemudian proses
terakhir adalah mengambil
tindakan perbaikan dan
perkembangan atas kekurangan
yang telah diketahui berdasarkan
evaluasi. Setelah proses tersebut
kemudian dapat mengetahui
perbaikan apa yang harus
dilakukan untuk perencanaan
program yang akan datang,
pengorganisasian, dan
pelaksanaannya.

\section{Daftar Pustaka}

Ahmad Juantika Nurihsan, Strategi Layanan Bimbingan \& Konseling, Bandung: PT. Refika Aditama, 2008.

Ahmad Juantika Nurihsan, Dasar-Dasar bimbingan dan Konseling, Bandung: Mutiara, 2003.

Aip Badrujaman, Teori dan Aplikasi Evaluasi Program bimbingan dan Konseling, Jakarta: PT Indeeks, 2011.

Depdiknas, Penataan Pendidikan profesional Konselor dan Layanan Bimbingan dan Konseling dalam Jalur pendidikan Formal, Jakarta: Depdiknas, 2008.

Dewa Ketut Sukardi, Manajemen Bimbingan dan Konseling, Bandung: Alfabeta, 2003.

Dewa Ketut Sukardi, Proses Bimbingan dan Konseling di Sekolah, Jakarta: Rineka Cipta, 2008.

Gibson, Robert L dan Marianne $\mathrm{H}$. Mitchell. 2011. Bimbingan dan Konseling. Yogyakarta: Pustaka Pelajar, 2011.

Hadawi Nawawi, Metodologi Penelitian Bidang Sosial, Yokyakarta: Gajah Mada University Pers, 2000. 
Hikmat, Manajemen Pendidikan. Bandung: Pustaka Setia, 2011.

Lexy J. Meleong, Metode Penelitian Kualitatif (Bandung: Remaja Rosdakarya, 2004.

Maliki, M.P.I. Bimbingan Konseling di Sekolah Dasar. Prenada Media, 2017.

Nana Syaodih Sukmadinata, Bimbingan dan Konseling dalam Praktek, Bandung: Maestro, 2007.

Nana Syaodih Sukmadinata, Metode Penelitian Pendidikan, Bandung: UPI \& UPT Remaja Rosda Karya, 2005.

Prayitno, Seri Layanan Konseling: L1-L9. Padang: Universitas Negeri Padang, 2004.

Prayitno dan Erman Amti, Dasar-Dasar Bimbingan dan Konseling. Jakarta: Rineka Cipta, 2004.

Ridwan, Penanganan Efektif Bimbingan dan Konseling di Sekolah, Yogyakarta: Pustaka Pelajar, 2008.

Santoadi, Fajar, Manajemen Bimbingan dan Konseling Komprehensif, Yogyakarta: USD, 2010.

Saring Marsudi, Layanan Bimbingan dan Konseling di Sekolah, Surakarta: Muhammadiyah University Press, 2010
Sutrisno Hadi, Metodologi Research Jilid 1, Yogyakarta: Andi Offset, 2001.

Sugiyono, Metode Penelitian Pendidikan Pendekatan Kuantitatif, Kualitatif dan R\&D, Bandung: Alfabeta, 2008. Sugiyo, Manajemen Bimbingan dan Konseling di Sekolah. Semarang: Widya Karya, 2011.

Syamsu Yusuf \& Juantika Nurihsan, Landasan Bimbingan dan Konseling, Bandung: PT. Remaja Rosdakarya, 2006.

Syamsu Yusuf. Program Bimbingan dan Konseling di Sekolah, Bandung. Rizqi Press,2009.

Thantawy, Manajemen Bimbingan dan Konseling, Jakarta: Pamator Pressindo, 1999.

Tim Penyusun, Penataan Pendidikan Profesional Konselor dan Layanan Bimbingan dan Konseling dalam Jalur Pendidikan Formal, Jakarta: Depdiknas, 2007.

Tohirin, Bimbingan dan Konseling di Sekolah dan Madrasah, Jakarta: PT. Raja Grafindo Persada, 2007.

Uman suherman, Manajemen Bimbingan dan Konseling, Jakarta: Madani Production, 2007. 